\title{
By-land-forskjeller i barns vekst
}

\section{Bybarn er høyere og tyngre enn barn i rurale strøk i de fleste lavinntekts- og mellominntektsland. Det er regionale forskjeller, men hovedtendensen er at forskjellene blir mindre.}

All low-income and middle-income countries
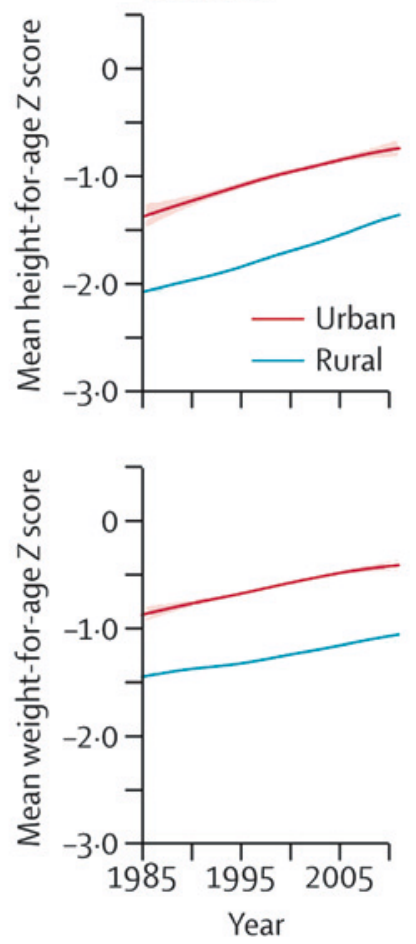

Gjengitt med tillatelse av Lancet Global Health

Underernæring kan gi forsinket vekst hos barn, en risikofaktor for morbiditet og mortalitet. Vekstindikatorer kan derfor brukes som mål på barns helsetilstand. I en ny studie analyseres forskjeller i høyde og vekt mellom urbane og rurale strøk i 141 lavinntekts- og mellominntektsland for perioden 1985-2011 (1). Man har brukt en database med vekstmål for 8,6 millioner barn.

Forskjellene i høyde og vekt mellom urbane og rurale områder var størst i enkelte deler av Latin-Amerika (Andes og MellomAmerikal samt $\mathrm{i}$ enkelte afrikanske land (Niger, Burundi og Burkina Faso) og i Vietnam og Kina, mens forskjellene var minst $i$ sørlige og tropiske deler av Latin-Amerika, bl.a. Chile og Brasil. Ytterpunktene i lengdevekst illustreres av at femåringer i urbane deler av Kina, Chile og Jamaica i gjennomsnitt var over $10 \mathrm{~cm}$ høyere enn femåringer $\mathrm{i}$ Burundi, Guatemala, Niger, Jemen og Afghanistan. De mest undervektige barna ble funnet i rurale strøk i Øst-Timor, India, Niger og Bangladesh.

\section{Sub-Saharan Africa}
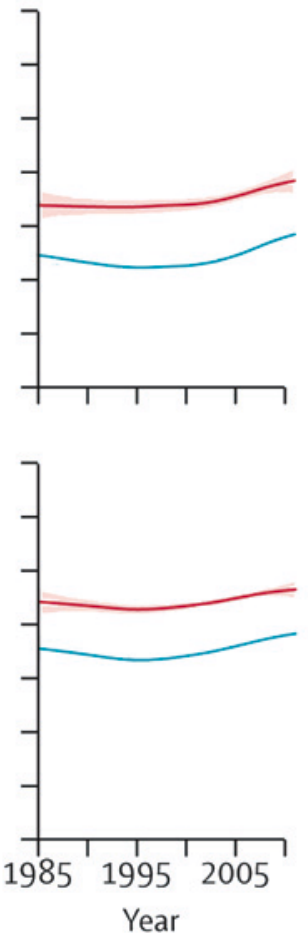

Estimert antall barn med dårlig lengdevekst (stunting) falt fra totalt 239 millioner i 1985 til 163 millioner i 2011. For 100 av landene ble forskjellene i høyde mellom rurale og urbane strøk mindre i løpet av denne perioden, det gjelder særlig Syria, Bangladesh, Thailand, Brasil og Indonesia. I de resterende 41 landene økte forskjellene, spesielt i Vietnam, Mali, Kamerun og Niger. For de fleste regionene var det en positiv tendens for både rurale og urbane strøk, men dette gjaldt ikke Afrika sør for Sahara.

\section{Kristoffer Brodwall}

Institutt for global helse og samfunnsmedisin Universitetet i Bergen

\section{Litteratur}

1. Paciorek C, Stevens GA, Finucane MM et al. Children's height and weight in rural and urban populations in low-income and middle-income countries: a systematic analysis of population-representative data. Lancet Global Health 2013; 1: e300-9.

\section{Kan preklinisk Alzheimers sykdom oppdages hos friske eldre?}

Analyse av spinalvæsken hos eldre personer uten kjent demens kan forutsi risikoen for Alzheimers sykdom.

I en amerikansk kohortstudie ble forekomsten av biomarkører for Alzheimers sykdom, dvs. betamyloid, fosforylert tau og total tau, undersøkt i spinalvæsken hos mer enn 300 eldre uten kjent demens. De gjennomgikk standardiserte tester av hukommelse og kognitive ferdigheter. Deltakerne ble inndelt i fem kategorier basert på analyseresultatene og hukommelsesskår. Omtrent hver tredje deltaker oppfylte kriteriene for ett av tre definerte forstadier til Alzheimers sykdom. Disse hadde økt risiko for progrediering av kognitiv svikt og for å utvikle Alzheimers sykdom og hadde høyere mortalitet (hasardratio 6,2; $95 \%$ KI 1,1-35,0; p = 0,04). Funnene tyder på at forstadier til Alzheimers sykdom kan påvises ved å måle biomarkører i spinalvæske, noe som kan tenkes å åpne for tidlig behandling.

- At det er forstadier til Alzheimers sykdom hos personer uten symptomer på demens er svært interessant, sier overlege Sigurd Sparr ved Geriatrisk seksjon ved Universitetssykehuset Nord-Norge. - Foreløpig har dette liten klinisk betydning, ettersom det ikke finnes behandling som kan stoppe sykdomsprosessen, spesielt ikke i et så tidlig stadium. Det er også problematisk å basere seg for mye på slike biomarkører, siden funn i spinalvæske ikke er entydige og kan være falskt positive. Videre forskning på tidlig demensdiagnostikk bør i større grad være basert på mindre invasive prosedyrer, som for eksempel blodprøver, sier Sparr.

\section{Tor Atle Rosness}

Tidsskriftet

Litteratur

1. Vos SJ, Xiong C, Visser PJ et al. Preclinical Alzheimer's disease and its outcome: a longitudinal cohort study. Lancet Neurol 2013; 12: 957-65. 